\title{
Assimilation of shrimp farm sediment by Holothuria scabra: a coupled fatty acid and stable isotope approach
}

\author{
Margaux Mathieu-Resuge ${ }^{1}$, Fabienne Le Grand ${ }^{1}$, Gauthier Schaal ${ }^{1,}$, Edouard Kraffe ${ }^{1}$, Anne Lorrain ${ }^{1}$, \\ Yves Letourneur ${ }^{2}$, Hugues Lemonnier ${ }^{3}$, Julie Benoît ${ }^{4}$ and Sébastien Hochard ${ }^{4}$ \\ ${ }^{1}$ Laboratoire des Sciences de l'Environnement Marin, UMR 6539 UBO/CNRS/IRD/IFREMER, Rue Dumont d’Urville, 29280 Plouzané, \\ France \\ ${ }^{2}$ Université de la Nouvelle-Calédonie, UMR Entropie and LabEx Corail, BP R4, 98851 Nouméa Cedex, New Caledonia \\ ${ }^{3}$ Institut Français de Recherche pour l'Exploitation de la Mer. Unité Lagons, Ecosystèmes et Aquaculture Durable en Nouvelle \\ Calédonie, BP 2059, 98846 Nouméa Cedex, New Caledonia \\ ${ }^{4}$ Agence de Développement Economique de la Nouvelle-Calédonie - ZoNéCo, BP 2384, 98846 Nouméa Cedex, New Caledonia
}

Received 22 July 2019 / Accepted 16 March 2020

Handling Editor: Verena Trenkel

\begin{abstract}
Deposit-feeding sea cucumbers are efficient nutrient recyclers and have the potential to contribute to the limitation of organic matter load in polyculture or integrated aquaculture systems. Assessing how they assimilate organic matter originating from other farmed species is therefore important for the development of such multi-species farming systems. Here, a coupled stable isotope - fatty acid approach was used to characterize the assimilation of organic matter from shrimp (Penaeus stylirostris) farming by Holothuria scabra in an experimental culture system. H. scabra were reared in mesocosms on shrimp farming-originating sediment with and without additional food sources (maize and fish meals). Although fatty acid results did indicate that shrimp-farming sediment was assimilated by holothurids, we found no evidence of maize waste and fish meal contribution to $H$. scabra organic carbon (no effect on $\delta^{13} \mathrm{C}$, no accumulation of meal-specific fatty acids). However, a strong effect of fish meal on $H$. scabra $\delta^{15} \mathrm{~N}$ was observed, suggesting that this additional food source could represent an alternative source of nitrogen for holothurids. Finally, this study supports the culture of H. scabra as a perspective to reduce sedimentary organic matter excess associated with shrimp farms, and suggest that the addition of selected food sources might contribute to increasing the content in some nitrogen organic compounds in holothurid tissues.
\end{abstract}

Keywords: Fatty acids / stable isotopes / rotational co-culture / shrimp-farming / Holothurid

\section{Introduction}

The combined farming of different species, where each one feeds on wastes from the other one (commonly referred to as polyculture, co-culture, or integrated culture Lutz, 2003; Zamora et al., 2016) aims at increasing economic yields of aquaculture surfaces, reducing ultimate effluents from production units and generating a mass-balanced system mitigating impacts on the adjacent environment (Soto, 2009). Sea cucumbers are considered as ideal models for co-culture systems in association with various taxa (molluscs, crustaceans, fish, seaweed) in both temperate and tropical environments (Zamora et al., 2016). Their high economic value makes them an attractive aquaculture product, with an annual

*Corresponding author: Gauthier.Schaal@univ-brest.fr production evaluated at $166712 \mathrm{t}$ in 2012-2014 (Zhang et al., 2015; Zamora et al., 2016).

Most holothurids in the order Aspidochirotida (e.g. Holothuria scabra, Apostichopus japonicus) are surface or sub-surface deposit-feeders, and can efficiently extract organic matter from coastal sediments (Roberts et al., 2003), which can contribute to mitigate aquaculture environmental impacts through the recycling of organic matter (Zamora et al., 2016). In Réunion Island (SW Indian Ocean), a mixed population of Holothuria atra and Holothuria leucospilota has been observed to ingest up to $82 \mathrm{~kg} \mathrm{~m}^{-2} \mathrm{y}^{-1}$ of sediment, with an organic matter assimilation efficiency of 10\% (Mangion et al., 2004). Individuals of $H$. scabra averaging $1 \mathrm{~kg}$ were reported to displace more than $250 \mathrm{~cm}^{3}$ of sediments per diurnal cycle (Purcell, 2004). Besides, their burrowing activity limits sediment hypoxia, thereby enhancing organic matter bacterial remineralization (MacTavish et al., 2012). Both H. scabra and 
A. japonicas have been considered as good candidate to be used in association with other species (i.e. crustaceans, molluscs, fish, seaweeds), in order to limit detrimental effects of organic matter accumulation on the sediment (e.g. Slater and Carton 2007; Watanabe et al., 2012; Neofitou et al., 2019; Zamora et al., 2016). In particular, their ability to selectively extract specific components of sedimentary organic matter, such as bacteria, nitrogen and transparent exopolymer particles (Moriarty 1982; Roberts et al., 2003; Robinson et al., 2016; Sadeghi-Nassaj et al., 2018), may suggest that their use in co-culture systems is relevant. Indeed, their use can contribute to remediate or manage the risks associated with pond sediment degradation in aquaculture ponds, where high densities and/or dystrophy conditions typically result in animal health issues (Lemonnier et al., 2006; Lemonnier, 2007). However, the selective assimilation of specific components of sediment is still poorly documented (but see Moriarty, 1982), especially in the context of high sedimentary organic enrichment (Gao et al., 2011; Slater et al., 2011; Yu et al., 2015; Zamora and Jeffs, 2015), such as for animals reared on aquaculture sediment. In particular, although addition of extra food is generally not required, it has recently been suggested that growth performances of holothurids could be improved through the addition of additional material to the system (Gao et al., 2011; Robinson et al., 2018, 2019).

In this context, trophic biomarkers, such as stable isotopes (SI) $\delta^{13} \mathrm{C}$ and $\delta^{15} \mathrm{~N}$, and fatty acids (FA) are powerful approaches to characterize the diet of marine organisms and assess the pathways of organic matter within food webs. Different food sources usually display different SI compositions, and the SI composition of a consumer reflects its food source, plus a small heavy isotope enrichment, usually $\approx 1 \%$ for carbon and $\approx 3.4 \%$ for nitrogen (Vander Zanden and Rasmussen, 2001). SI have been successfully used to investigate the trophic ecology of sea cucumbers (Slater and Carton, 2010) and their trophic relationships in a polyculture system (Feng et al., 2014). In spite of their usefulness in discriminating food sources contributing to the diet of consumers in low food source diversity systems, SI provide a limited resolution for heterogeneous organic matter pools, such as sediment or suspended particulate organic matter. Due to the higher taxa specificity of FA, their analysis is complementary to SI to investigate the composition of such heterogeneous organic matter pools (Kharlamenko et al., 2001). The existence of bacteria, diatom, flagellate and higher plant specific FA makes this approach extremely powerful to disentangle trophic relationships for sediment-associated organisms that might be overlooked otherwise when using bulk SI alone (Kelly and Scheibling, 2012).

The Pacific blue shrimp (Penaeus stylirostris Stimpson, 1974 ) is the second export product of New Caledonia. The island hosts 19 shrimp farms, for an annual production of ca. 2000 tons.year $^{-1}$ (Lemonnier, 2007). Shrimp farming occurs on ponds varying between 4 and 11 ha, where shrimp densities range from 18 to 35 individuals $\mathrm{m}^{-2}$ (Della Patrona and Brun, 2008). The accumulation of uneaten food pellets on sediments results in shrimp ponds eutrophication, ultimately favoring the development of pathogens (Lemonnier et al., 2010). The co-culture of shrimps and sea-cucumbers (Purcell et al., 2006; $\mathrm{Xu}$ and Zhu, 2002), or their polyculture with jellyfish (Li et al., $2014 b, 2014 a$ ) has therefore been considered as an alternative to limited the organic matter excess from shrimp monocultures. Moreover, studies revealed that shrimp wastes could be used to feed sea cucumbers (Chen et al., 2015a, 2015b). These co-culture systems could (1) limit sediment organic enrichment (Slater and Carton, 2007) and (2) develop a new high value exportation pathway. Because simultaneous culture of these two species has been proven deleterious to juvenile sea cucumbers (Bell et al., 2007; Pitt et al., 2004), a rotational culture system, where sea cucumbers are reared in ponds after extraction of shrimps, seems to be the most relevant system.

In this context, the first objective of the present study was to evaluate the assimilation of shrimp farm sediments by $H$. scabra, simulating a context of a P. stylirostris - H. scabra rotational co-culture system. In a second time, the study tried to assess the relevance of using additional food sources, by characterizing the assimilation of two potential sources (i.e. maize meal and fish meals) in the tissues of the holoturids. Maize meal is a potential low-cost and easily available food supplement which can stimulate the benthic food web through heterotrophic assimilation. Fish meal is more expensive, but also of higher nutritional value. The assimilation of these different food sources by juvenile sea cucumbers was assessed through a combined SI $\left(\delta^{13} \mathrm{C}, \delta^{15} \mathrm{~N}\right)$ and FA approach.

\section{Material and methods}

\subsection{Experimental setup}

Experiments were conducted at the experimental station of Saint-Vincent Bay $\left(21^{\circ} 58^{\prime} \mathrm{S}, 165^{\circ} 57^{\prime} \mathrm{E}\right.$; New Caledonia) for 7 months, between April and December 2014. Ten mesocosms of $1600 \mathrm{~L}\left(1.72 \mathrm{~m}^{2}\right)$ were each filled with $25 \mathrm{~cm}$ of sediment from upper $5 \mathrm{~cm}$ of a semi-intensive shrimp farm, collected at the end of a shrimp growing period after 3 weeks of dry out, and presenting a content in organic matter of $2.3 \%$, and ammonium concentrations higher than $1000 \mu \mathrm{mol} \cdot \mathrm{L}^{-1}$. Mesocosms were filled with seawater on open circuit, with an average daily water renewal of $30 \%$. Juveniles $H$. scabra (initial weight $=15.2 \pm 0.2 \mathrm{~g}$ ) were then placed in 9 tanks at a density of 7 indivuduals $\cdot \mathrm{m}^{-2}$ (12 individuals per tank). One tank was left without animals as a control for the natural evolution of shrimp farm sediment. The $9 \mathrm{H}$. scabra tanks were then randomly assigned to a treatment (3 replicates / treatment): (1) animals reared on shrimp farm sediment only (unenriched treatment), (2) animals reared on shrimp farm sediment + maize meal (added twice a week, eq. $1.5 \%$ of initial biomass $\cdot \mathrm{d}^{-1}$ ) and (3) animals reared on shrimp farm sediment + fish meal (added twice a week, eq. $1.5 \%$ of initial biomass $\left.\cdot \mathrm{d}^{-1}\right)$. Fish meal was gently spread in the mesocosms to ensure a uniform repartition. Maize meal was hydrated with mesocosm water to make sure it will not float, and then gently spread as for fish meal. Fecal pellets and uneaten food were not removed during the experiment.

\subsection{Sampling}

Because of the limited number of animals available for each treatment, and in order to limit density modifications inside each tank, which could lead to unpredictable densitydependent processes, a limited number of individuals were sampled at each sampling time. Five individuals were 
randomly sampled at the beginning of the experiment $\left(\mathrm{T}_{0}\right)$, before the distribution of animals in the different mesocosms. During experiment, one individuals per tank (3 for each treatment) was sampled after 1 and 3 months $\left(\mathrm{T}_{2}\right.$ and $\left.\mathrm{T}_{3}\right)$, and 3 individuals per tank ( 9 for each treatment) were sampled after 7 months $\left(\mathrm{T}_{\mathrm{f}}\right)$, at the end of the experiment. At each sampling time, sampled individuals were weighed and then dissected in order to collect muscle strips for SI and FA analyses. The sampling of the muscle allowed analysing the same tissues during the all experiment, while gonads were not developed at the beginning of the experiment. Two sub-samples were taken for FA and SI analyses, respectively, and then stored at $-80^{\circ} \mathrm{C}$ before further analyses. Every month, the medium weight of animals was assessed for each tank, and mortality was assessed at the end of the experiment through total fishing of the tank.

Surface sediment (upper $5 \mathrm{~cm}$ ) was also sampled (three $2.6 \mathrm{~cm}$ diameter cores pooled for each tank) at $\mathrm{T}_{0}$ and after 1,3 and 7 months (end of experiment). Biofilm covering mesocosm walls was also sampled at the end of the experiment by scraping. Fish meal and maize meals distributed to the additional food source treatments throughout the experiment did originate from the same initial stocks, and were therefore sampled at the beginning of the experiment for SI and FA analyses. All these samples were stored at $-80^{\circ} \mathrm{C}$ before further analyses.

\subsection{Laboratory analyses}

\subsubsection{Stable isotope analyses}

Muscle samples, biofilm, maize and fish meals were freeze-dried and ground with a mortar and a pestle into a fine and homogeneous powder. About $0.5 \mathrm{~g}$ of muscle, $1 \mathrm{mg}$ of sediment, biofilm, and additional food sources were placed in tin capsules. Sediment samples were split into 2 sub-samples for carbon and nitrogen analyses. As carbonates present higher $\delta^{13} \mathrm{C}$ than organic carbon, one was treated for $\delta^{13} \mathrm{C}$ analysis, after acidification by $1 \% \mathrm{HCl}$ solution to remove carbonates, rinsed with distilled water and oven-dried at $60^{\circ} \mathrm{C}$ for $24 \mathrm{~h}$ (DeNiro and Epstein, 1978). The other subsample for nitrogen isotope analysis was not acidified because acidification results in enrichment in $\delta^{15} \mathrm{~N}$ (Pinnegar and Polunin, 1999). The ${ }^{13} \mathrm{C}:{ }^{12} \mathrm{C}$ and ${ }^{15} \mathrm{~N}:{ }^{14} \mathrm{~N}$ ratios were measured by continuous-flow isotope-ratio mass spectrometry. The spectrometer (Delta V Advantage stable isotope analyzer, Thermo Scientific, Bremen, Germany, with Flash EA-1112elemental analyzer, Thermo Scientific, Milan, Italy) was operated in dual isotope mode. The analytical precision, estimated from standards analyzed along with the samples, was $<0.1 \%$ for $\delta^{13} \mathrm{C}$ and $<0.15 \%$ for $\delta^{15} \mathrm{~N}$. Reference gas and the internal standard used (acetanilide, Thermo Scientific) were calibrated against reference materials (USGS-24, IAEA-CH6, IAEA-600 for carbon; IAEA-N1,-N2, $-\mathrm{N} 3,-600$ for nitrogen). Data are expressed in the $\delta$ unit, in permil: $\delta \mathrm{X}=\left[\left(\mathrm{R}_{\text {sample }} / \mathrm{R}_{\text {standard }}\right)-1\right]$. $10^{3}$. Where $\mathrm{X}={ }^{13} \mathrm{C}$ or ${ }^{15} \mathrm{~N}$ and $\mathrm{R}={ }^{13} \mathrm{C} /{ }^{12} \mathrm{C}$ or ${ }^{15} \mathrm{~N} /{ }^{14} \mathrm{~N}$, respectively.

\subsubsection{Fatty acid analyses}

A known mass of muscle strips (between 20 and $100 \mathrm{mg}$ of wet weight, according to individual mass) was ground with a Dounce tissue grinder in $6 \mathrm{~mL}$ of chloroform:methanol
(2:1, v:v ; HPLC grade, Sigma-Aldrich). Samples were then sonicated $10 \mathrm{~min}$ at $4{ }^{\circ} \mathrm{C}$ in order to ensure complete lipid extraction. Lipids from sediment, biofilm and additional food sources were also extracted following this method. Lipid extracts were then stored at $-20^{\circ} \mathrm{C}$ under nitrogen atmosphere after addition $0.01 \%$ by weight of butylated hydroxytoluene (Sigma-Aldrich) as antioxidant, before analysis. After evaporation to dryness under nitrogen and recovering with three washings of $0.5 \mathrm{~mL}$ chloroform:methanol $(98: 2, \mathrm{v}: \mathrm{v})$, an aliquot (1/5) of muscle lipid extract was deposited at the top of a silica gel (silica gel 60, 70-230 $\mu \mathrm{m}$ mesh, Sigma-Aldrich previously heated at $450{ }^{\circ} \mathrm{C}$ and deactivated with $6 \%$ water by weight) micro-column $(40 \mathrm{~mm} \times 5 \mathrm{~mm}$ i.d. $)$. Neutral lipids (NL) were eluted with $10 \mathrm{~mL}$ of chloroform:methanol (98:2, v:v) (Marty et al., 1992). NL are FA generally stored in consumer tissues in the same proportions than in their food sources, therefor they mirror the composition of the diet (here sediment, meals, and/or biofilm). In contrast, dietary lipids are assimilated without lipid classes distinction (Arts et al., 2001; Dalsgaard et al., 2003). For this reason, NL were separated from the total lipid pool only for sea cucumber samples, while total FA were analyzed for food sources (sediment, biofilm, meals). Lipids were then transesterified by adding of $800 \mu \mathrm{L}$ of $\mathrm{H}_{2} \mathrm{SO}_{4}$ (3.4\% v:v in methanol, Sigma Aldrich)as a catalyzer, $0.01 \%$ and tricosanoic acid (Sigma Aldrich) as an internal standard and heating $10 \mathrm{~min}$ at $100^{\circ} \mathrm{C}$. After cooling at room temperature and adding $800 \mu \mathrm{L}$ of hexane (HPLC grade, Sigma Aldrich), the organic phase-containing FA methyl esters (FAME) was washed three times with $1.5 \mathrm{~mL}$ of watersaturated hexane. FA methyl esters were then recovered and analyzed in a Varian CP 8400 gas chromatograph (GC) equipped with a splitless injector and a flame-ionization detector and using hydrogen as mobile phase. FA methyl esters were separated using a polar (ZB-WAX - $30 \mathrm{~m}$ x $0.25 \mathrm{~mm}$ i.d.; $0.25 \mu \mathrm{m}$ thickness, Phenomenex) and a non-polar (ZB-5HT $30 \mathrm{~m} \mathrm{x} 0.25 \mathrm{~mm}$ i.d.; $0.25 \mu \mathrm{m}$ thickness, Phenomenex) capillary columnsin parallel. Chromatograms were analyzed using the Galaxie software. The internal standard allowed FA quantification. FA were identified by comparing retention times with those of a commercial standard mixture containing 37 FAME (Sigma Aldrich) and other known standard mixtures (Le Grand et al., 2013). FA were designated following the general nomenclature $(\mathrm{X}: \mathrm{Yn}-\mathrm{Z})$ where $\mathrm{X}$ is the number of carbones, $\mathrm{Y}$, the number of double bounds and $\mathrm{Z}$ the position of the first double bound counting from the terminal methyl carbon toward the carbonyl carbon. Results were expressed as the proportion (mass percentage) of each FA on total FA of the total lipids (sediment, biofilm and meals) or of the neutral lipids (H. scabra).

\subsection{Data analyses}

Due to limited number of replicates for each time / treatment, the effects of treatment at each time on the SI composition, and for each individual NL FA of sea cucumbers were assessed through non parametric Kruskal-Wallis (KW) tests, followed by Conover-Iman multiple comparison tests with Bonferroni's adjustment method.

Only FA representing more than $1 \%$ of total FA were taken into account for data analysis. The global FA composition of sea cucumbers and sources was represented 
through non-metric mulitidimensional scalings (nMDS) based on Euclidean distances. The effects of time and treatments on the FA composition of sea cucumbers and sediments were assessed through permutational variance analyses (PERMANOVA). Because the number of replicates of potential food source (sediment, meals and biofilm) samples were lower or equal to 3 , it was not possible to compare the effect of treatment at each times by statistical analyses. All statistical analyses and graphics were performed with the free software R (Core Team, 2017), with R Version 3.4.1 (2017 06 30).

\section{Results}

\subsection{Survival and growth of animals}

Survival rates of sea-cucumbers at the end of the experiment ranged between $86.7 \pm 15.3 \%$ for fish meal treatment, to $90 \pm 17.3 \%$ and $90 \pm 10 \%$, for unenriched and maize meal treatments, respectively. They did not differ significantly among treatments (data not shown). Likewise, individual final weights did not differ among treatments, ranging from $37.3 \pm 9.1 \mathrm{~g}$ for individuals coming from unenriched treatment, to $40.6 \pm 13.8 \mathrm{~g}$ for individuals from fish meal treatment, and to $43.3 \pm 16.3 \mathrm{~g}$ for individuals from maize meal.

\subsection{Stable isotopes}

The SI composition of sediment did not vary significantly among treatments during the experiment (KW tests, for $\delta^{13} \mathrm{C} \mathrm{H} 25=2.39, p$-value $=0.30$; and for $\delta^{15} \mathrm{~N} \mathrm{H} 25=6.38$, $p$-value $=0.05$ ). None of the 3 treatments (unenriched, maize meal, fish meal) induced significant variation of sediment $\delta^{13} \mathrm{C}$ over time, values ranging between $-19.1 \%$ and $-18.3 \%$, $\left(\mathrm{KW}\right.$ tests; at $\mathrm{T}_{0} \mathrm{H} 25=1.69 p$-value $=0.43$; at $\mathrm{T}_{3} \mathrm{H} 25=2.85$, $p$-value $=0.24$; at $\mathrm{T}_{\mathrm{f}} \mathrm{H} 25=0.35, p$-value $\left.=0.84\right)$, or $\delta^{15} \mathrm{~N}$ over time $\left(\mathrm{KW}\right.$ tests; at $\mathrm{T}_{0} \mathrm{H} 25=3.01 p$-value $=0.22$; at $\mathrm{T}_{3}$ $\mathrm{H} 25=3.52, p$-value $=0.17$; at $\mathrm{T}_{\mathrm{f}} \mathrm{H} 25=5.6, p$-value $\left.=0.06\right)$, (Fig. 1). Biofilm ( $n=3$ for each treatment) covering mesocosms walls showed no significant differences of $\delta^{13} \mathrm{C}$ ( $\mathrm{KW}$ tests, $\mathrm{H} 25=4.86$, $p$-value $=0.09)$ between unenriched, maize and fish meal treatment at $\mathrm{T}_{\mathrm{f}}$. The post hoc test showed significant difference between $\delta^{15} \mathrm{~N}$ values from fish and unenriched treatments $(p$-value $<0.05)$. Among these 3 treatments, biofilm from unenriched mesocosms displayed the most ${ }^{13} \mathrm{C}$-enriched mean values $(-3.4 \%$ ), while fish meal addition resulted in the highest mean $\delta^{15} \mathrm{~N}$ values $(8.5 \%)$. The SI composition of maize $(n=2)$ and fish $(n=2)$ meals differed of $4.3 \%$ for the $\delta^{13} \mathrm{C}$ and of $7 \%$ for $\delta^{15} \mathrm{~N}\left(\delta^{13} \mathrm{C}=-12.5 \%\right.$ and $-16.8 \%$ and $\delta^{15} \mathrm{~N}=4.6 \%$ and $11.6 \%$ for maize and fish meals, respectively).

The $\delta^{15} \mathrm{~N}$ of $H$. scabra increased in all treatments during the experiment (Fig. 1). The $\delta^{15} \mathrm{~N}$ was significantly different among treatments only after 7 months (KW test, $\mathrm{H} 25=18.56$, $p$-value $<0.001)$. The highest values were found for fish meal treatment (from $6.0 \pm 0.6 \%$ at the beginning to $11.5 \pm 0.4 \%$ at the end of the experiment), significantly different from both other treatments (Conover-Iman multiple comparison tests with Bonferroni's adjustment, both $p$-values $<0.05$ ), while muscles of animals from unenriched and maize meal treatments displayed a lower and similar ${ }^{15} \mathrm{~N}$ enrichment
(7.6 $\pm 0.9 \%$ and $6.8 \pm 0.7 \%$, respectively, Conover-Iman multiple comparison tests with Bonferroni's adjustment, $p$-value $=0.18)$. The $\delta^{13} \mathrm{C}$ also displayed significant variations between treatments at the $T_{f}(\mathrm{KW}$ test, $\mathrm{H} 25=11.49$, $p$-value $<0.05)$. Muscles of animals from unenriched and fish meal treatments displayed significantly different $\delta^{13} \mathrm{C}$ values (Conover-Iman multiple comparison tests with Bonferroni's adjustment $p$-value $<0.001$ ), with muscles from unenriched treatment more ${ }^{13} \mathrm{C}$ enriched $(-11 \pm 0.8 \%$ ) than muscles from fish meal treatment $(-12.3 \pm 0.8 \%)$. Muscles of animals from maize meal treatment presented intermediate values $(-11.5 \pm 0.8 \%$ o $)$ showing no significant difference from both others treatments (Conover-Iman multiple comparison tests with Bonferroni's adjustment, $p$-value $=0.09$ and $p$-value $=$ 0.15 , when compare to fish and unenriched treatments, respectively).

\subsection{Fatty acids}

The global FA composition of sediments varied significantly among the different treatments (PERMANOVA, $p$-value $\left.<0.05, \mathrm{df}=3, R^{2}=0.19\right)$, with all sampling times combined. The FA composition of sediment was dominated by saturated fatty acids (SFA) in the 3 different treatments during all the experiment ( $\Sigma$ SFA ranging from $41.0 \%$ to $47.0 \%$; Tab. 1). All sediment samples but one (maize meal, dominated by $15: 0$ ) were dominated by $16: 0$, and included less than $10 \%$ of poly-unsaturated fatty acids (PUFA) (Tab. 1). Even though these differences were supported by slight variations in specific FA, higher levels of 15:0 and 17:1n-8 were found in maize meal sediment, as well as higher levels of branched FA for unenriched and fish meal treatments (Tab. 1). FA whose abundance differed the most between maize and fish meal (18:1n-9, 18:2n6, 20:5n-3 and 22:6n-6, Tab. 2) showed slight variations in sediments from the different treatments (Tab. 1). A higher amount of branched FA was observed in the composition of sediments from unenriched and fish meal treatments at the end of the experiment.

Biofilm contained a higher proportion of PUFA than sediment (between $24.3 \%$ and $27.9 \%$, Tab. 2) with $20: 5 n-3$ accounting for $7.6 \%$ to $10.5 \%$ of total FA and $20: 4 n-6$ reaching $\pm 4 \%$, while $22: 6 \mathrm{n}-3$ was almost absent from biofilms from the 3 different conditions (Tab. 2). SFA were still dominant, accounting for $35.9 \%$ to $38.6 \%$, with $16: 0$ as the principal SFA (Tab. 1). The biofilm was also characterized by high proportions of $16: 1 n-7$ for the three treatment, while $16: 1 n$ 9 and 18:1n-9 were found in higher levels in biofilm that developed in tanks supplemented with maize and fish meal (Tab. 2).

Maize and fish meals supplemented to shrimp farm sediment during the experiment displayed highly contrasted FA compositions. Both food sources were dominated by PUFA (between $39.6 \%$ and $42.1 \%$ of total FA; Tab. 2). Maize meal showed higher levels of monounsaturated FA (MUFA) than fish meals (29.2\% and 22.4\%, respectively; Tab. 2) and SFA were higher in fish meal than in maize meal $(34.9 \%$ and $28.4 \%$, respectively; Tab. 2). These two food sources differed markedly in the composition of a few major FA. 18:1n-9 accounted for $26.5 \%$ in maize but for only $7.7 \%$ in fish meal (Tab. 2). Similarly, $18: 2 n-6$ accounted for $38.7 \%$ of total FA in 

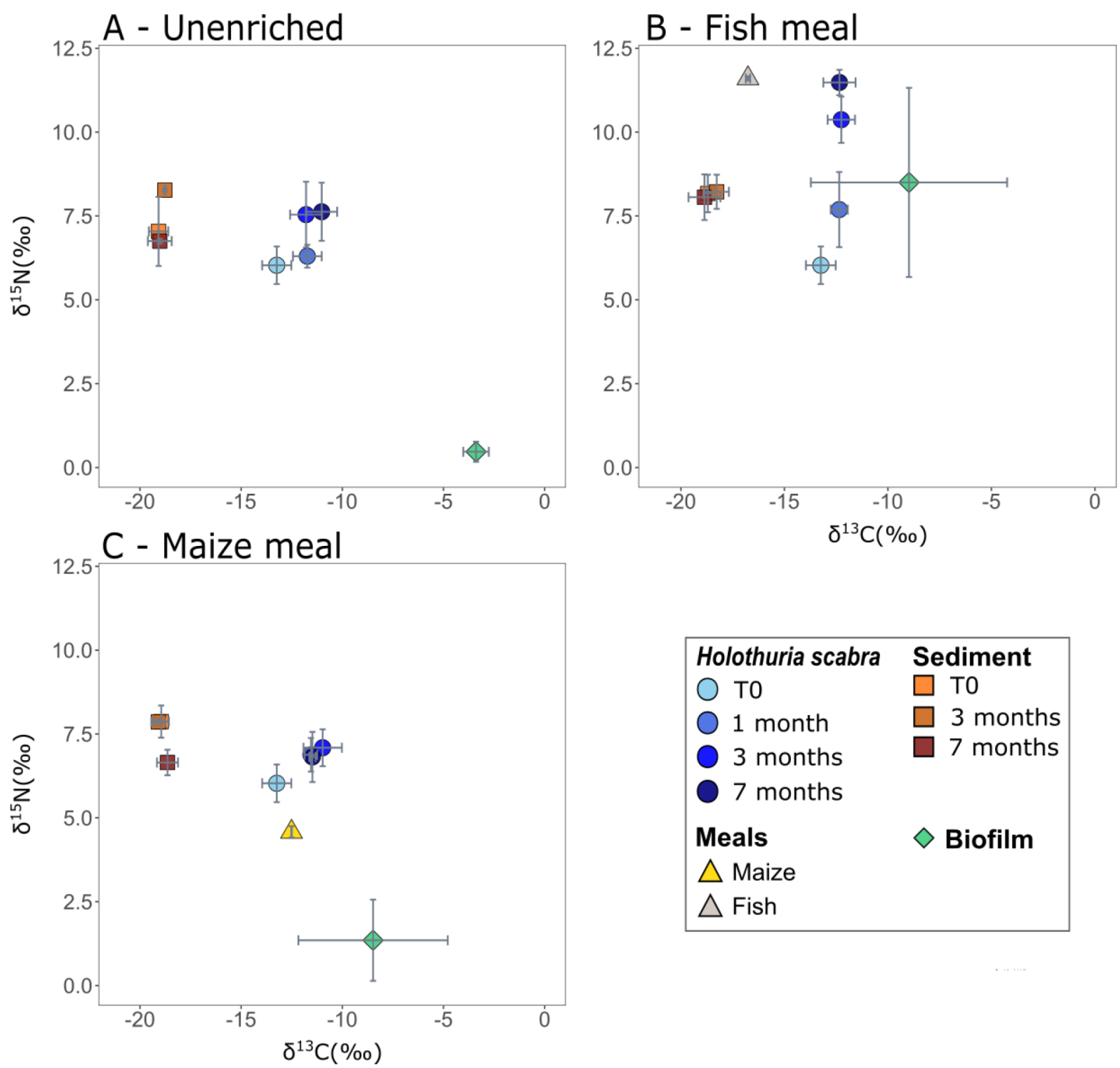

\begin{tabular}{|ll|}
\hline Holothuria scabra & Sediment \\
$\bigcirc$ T0 & $\square$ T0 \\
$\bigcirc 1$ month & $\square 3$ months \\
3 months & $\square 7$ months \\
7 months & \\
Meals & $\diamond$ Biofilm \\
$\triangle$ Maize & \\
$\triangle$ Fish & \\
\hline
\end{tabular}

Fig. 1. $\delta^{13} \mathrm{C}$ vs. $\delta^{15} \mathrm{~N}$ (mean \pm S.D.) of Holothuria scabra and its potential food sources (sediment. biofilm. maize ad fish meals) during the feeding experiment. H. scabra reared on shrimp-farm sediment only (unenriched treatment) (A). H. scabra reared on shrimp-farm sediment and fishmeal (B) and H. scabra reared on shrimp-farm sediment and maizemeal (C). Fish and maize meal stable isotope compositions did not vary through the experiment.

maize meal but only for $0.9 \%$ in fish meal. $20: 5 n-3$ and $22: 6 n-3$ were in much higher proportions in fish meal than in maize meal, accounting for $14.8 \%$ and $11.1 \%$ of fish meal total FA, respectively, while these FA were virtually absent from maize meal (Tab. 2).

We found no significant interaction between time and treatment in the composition of in $H$. scabra $\mathrm{NL}$ (PERMANOVA, $\quad p$-value $\left.=0.39, \quad \mathrm{df}=2, \quad R^{2}=0.04\right)$. The global composition of NL varied over time (PERMANOVA, $p$-value $\left.<0.001, \mathrm{df}=2, R^{2}=0.08\right)$, and between the different treatments (PERMANOVA, $p$-value $<0.05, \mathrm{df}=4, R^{2}=0.09$ ). For the three treatments and the three sampling times, NL FA in $H$. scabra muscle strips were dominated by SFA (between $31.0 \%$ and $45.2 \%$ ), while MUFA ranged from $21.2 \%$ to $31.8 \%$ and PUFA from $14.0 \%$ to $26.9 \%$ (Tab. 3). The content of branched FA ranged from $1.6 \%$ to $7.5 \%$ (Tab. 3). The main
SFA were 16:0 (between 7.9\% and 13.7\%) and 18:0 (between $7.3 \%$ and $17.7 \%$ ). The most abundant MUFA was $18: 1 \mathrm{n}-9$ (from $3.96 \%$ to $7.7 \%$ ), while PUFA were dominated by $20: 4 n-$ 6 (from $4.3 \%$ to $12.3 \%$ ) and $20: 5 n-3$ (from $2.9 \%$ to $7.9 \%$ ) (Tab. 3).

The NL FA composition of $H$. scabra in unenriched treatment varied significantly over the experiment (PERMANOVA, $p$-value $<0.001, \mathrm{df}=2, R^{2}=0.34$; Fig. $2 \mathrm{~A}$ ), due to an initial strong increase in PUFA (mainly 20:4n-6 and 20:5n-3) from $\mathrm{T}_{0}$ to after 3 months of experiment, then a slight decrease was observed after the 7 months of experiment (Tab. 3 and Fig. 2A). The NL FA composition of individuals from fish meal treatment was also significantly different over time (PERMANOVA, $p$-value $<0.001, \mathrm{df}=2, R^{2}=0.31$; Fig. 2B), as for individuals from maize meal treatment (PERMANOVA, $p$-value $<0.05, \mathrm{df}=2, R^{2}=0.26$; Fig. $2 \mathrm{C}$ ). 
Table 1. Fatty acid composition (mass $\%$ of total FA, mean \pm S.D.) of sediment from the different treatments at the beginning of the experiment $\left(\mathrm{T}_{0}\right)$, after 3 month, and after 7 months ( $n=3$ for each time). SFA: saturated FA; MUFA: monounsaturated FA; PUFA: polyunsaturated FA; Branched: FA [15iso+15anteiso+16iso+17iso+17anteiso $]$.

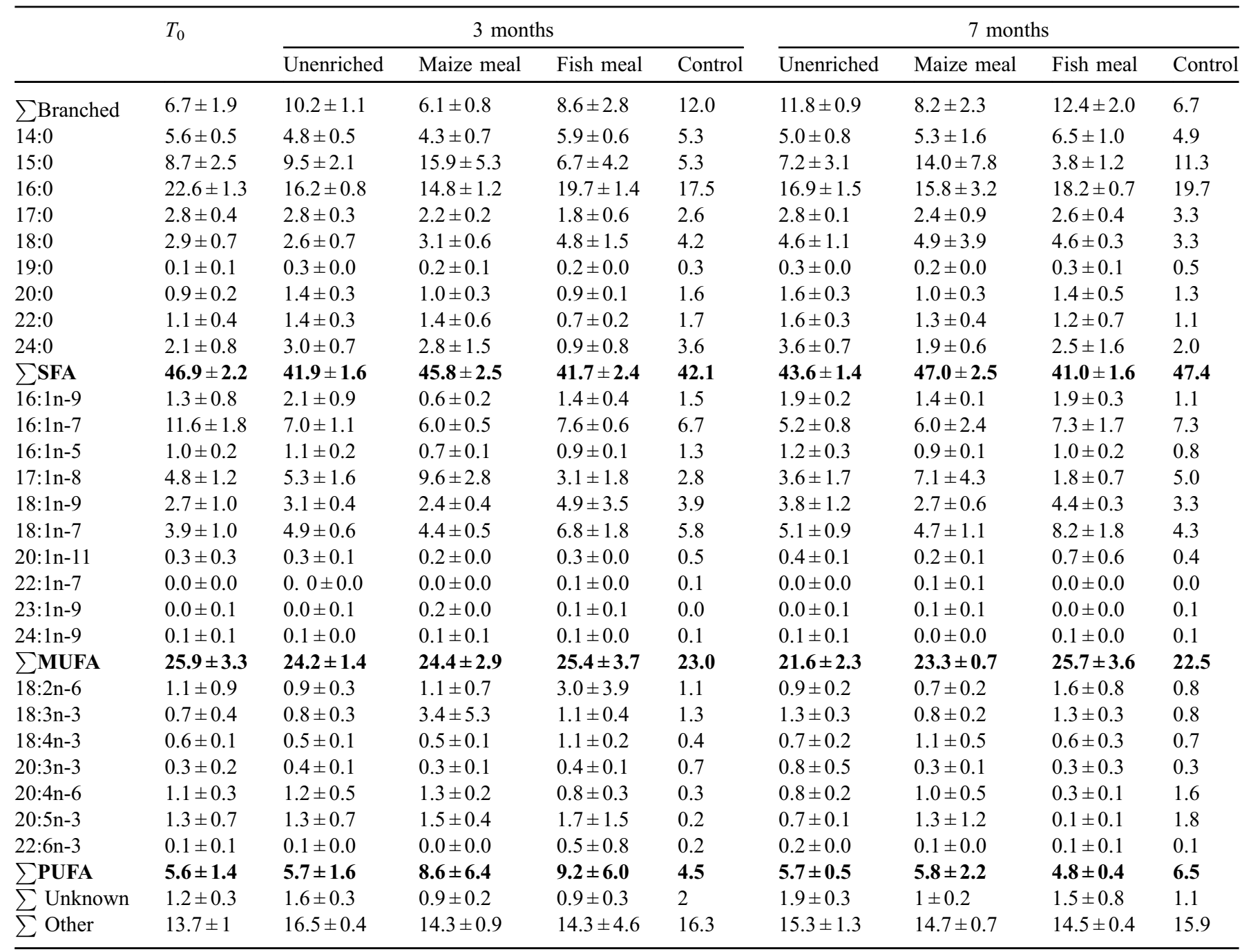

However, we found a strong overlap in the FA composition of sea cucumbers from the different treatments, owing to a strong inter-tank variability (Fig. 2D). At the end of the experiment, individuals fed maize meal were characterized by high $(>5 \%)$ content in 16:0, 18:0, 16:1n-9 and 20:3n-3, while individuals fed fish meal displayed high content in branched FA, 16:0 and 18:0 (Tab. 3). Branched FA were found in significant higher amount in $H$. scabra having received additional meals, especially for fish meal treatment, and at intermediate levels in animals fed on maize meal (Tab. 3).

\section{Discussion}

\subsection{Stable isotope and fatty acid composition of potential food sources}

Although maize and fish meal displayed contrasted SI and FA compositions, the addition of these food sources did not result in significant differences in the SI composition of sediments. A first explanation of this result could be that external inputs are diluted in a larger volume of underlying sediment. This would result in buffering any isotopic variations due to these inputs. However, additional isotopic measurements carried out on surface sediment did not reveal any significant differences compared to those presented, suggesting that these additional food sources did not accumulate on the bottom of the mesocosms (data not shown). It is therefore more likely that these sources are consumed, either by $H$. scabra and/or by micro-organisms (Yokoyama, 2013; Robinson et al., 2018). The consumption of maize/fish meals by $H$. scabra and/or by micro-organisms would release inorganic nutrients that could enhance the growth of fast-growing primary producers forming biofilm, such as filamentous algae or bacteria. This is supported by isotopic differences in biofilms covering the mesocosms' walls, which follow isotopic differences in external sources (i.e. ${ }^{15} \mathrm{~N}$ enriched for fish meal, ${ }^{13} \mathrm{C}$ enriched for maize meal). 
Table 2. Fatty acid composition (mass $\%$ of total FA, mean \pm S.D.) of biofilm (after 7 months) $(n=3)$, maize and fish meals $(n=2)$. SFA: saturated FA; MUFA: monounsaturated FA; PUFA: polyunsaturated FA; Branched: FA [15iso +15 anteiso +16 iso +17 iso +17 anteiso].

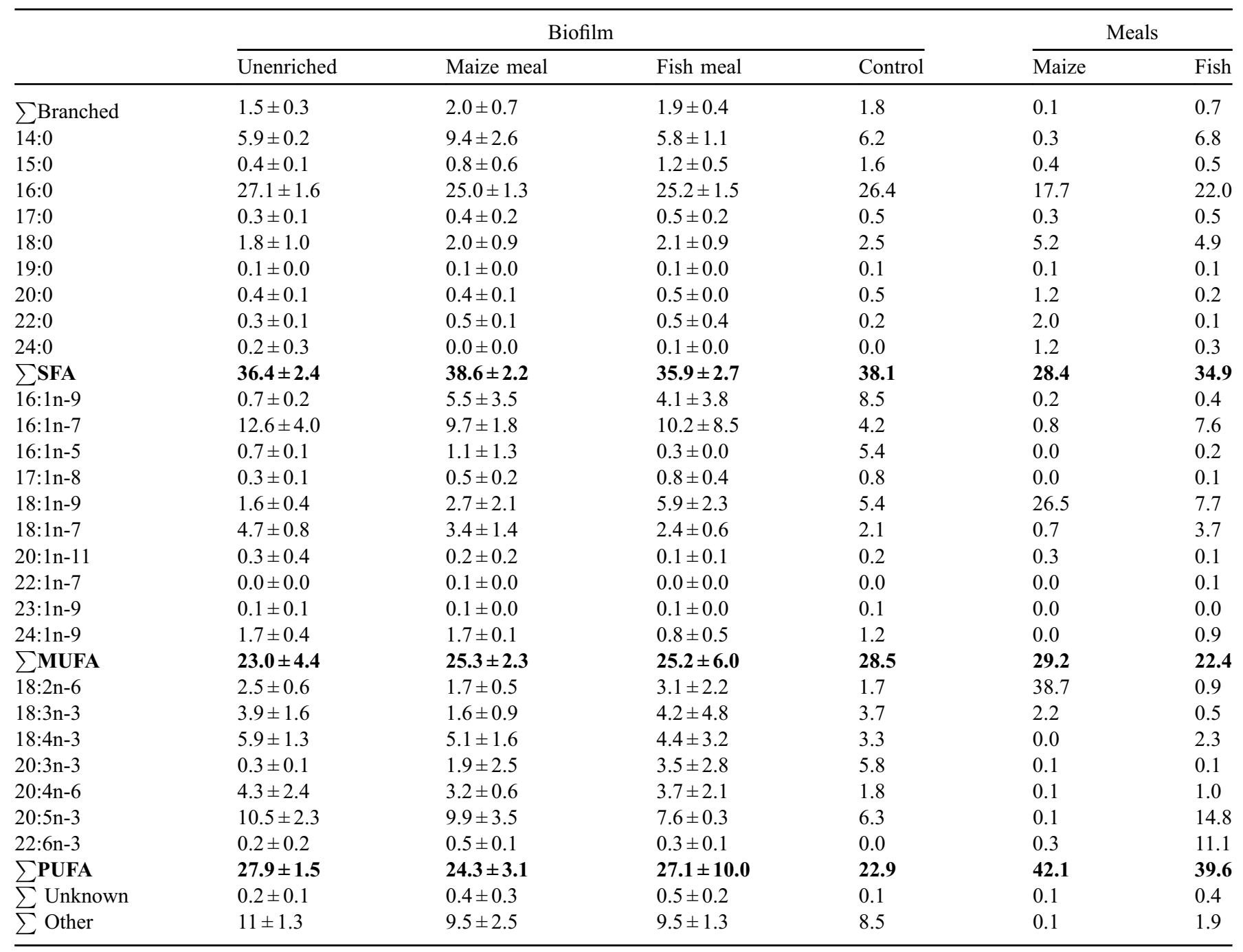

The FA composition of sediment was dominated by SFA, which is common for detritus-dominated sediments (Kelly and Scheibling, 2012). Although the overall FA composition did not vary during the experiment, sediment at the beginning of the experiment was characterized by significant amounts of $16: 1 n-7$, which is generally considered to be abundant in diatoms (Dalsgaard et al., 2003). The amount of this FA decreased during the experiment in the 3 treatments, simultaneously with an increase in branched FA and in 18:1n-7, which have been reported specific to bacteria in tropical environments (Meziane and Tsuchiya, 2000). These results reinforce the previous hypothesis of external food sources being metabolized by bacteria in supplemented treatments. The increase in bacterial FA is also observed in non-enriched treatment, which suggests a natural trend to favor bacterial development of high organic matter shrimp-farm sediments (Burford et al., 1998).

The FA composition of biofilm was also investigated, because $H$. scabra was sometimes observed foraging at the vicinity of tank walls. At the end of the experiment, the FA composition of biofilm was dominated by $16: 1 n-7,18: 1 n-7$ and 20:5n-3, which are biomarkers of diatoms and bacteria (Kharlamenko et al., 2001; Meziane and Tsuchiya, 2000). Higher content in $18: 3 n-3,18: 4 n-3$ and 20:3n-3 compared to sediments was also observed, and can be explained by the presence of filamentous Phaeophyta on the walls of mesocosms (Volkman et al., 1989; Kharlamenko et al., 2001).

\subsection{Assimilation of shrimp farm sediment by $H$. scabra}

The temporal variation of $H$. scabra SI composition for unenriched treatment revealed slight $\delta^{13} \mathrm{C}$ and $\delta^{15} \mathrm{~N}$ increases during the experiment $(+2.2 \%$ and $+1.6 \%$, respectively). Although at $\mathrm{T}_{\mathrm{f}}$, SI composition of $H$. scabra seems too ${ }^{13} \mathrm{C}$ enriched to reveal a diet only based on sedimentary organic matter, this temporal variation could reveal either a diet based on both sedimentary organic matter and biofilm, or dominated 
Table 3. Fatty acid composition (mass $\%$ of total FA, mean \pm S.D.) of the neutral lipids of Holothuria scabra fed the different treatments at the beginning of the experiment $\left(\mathrm{T}_{0}\right)(n=5)$, after 3 months $(n=3$ for each treatment) and after 7 months $(n=9$ for each treatment). Different letters indicate significant differences (KW tests followed by Conover-Iman multiple comparison tests with Bonferroni's adjustment method, at significant level $\alpha<0.05$ ), indicating variations of FA compositions between treatment at 3 months and 7 months. SFA: saturated FA; MUFA: monounsaturated FA; PUFA: polyunsaturated FA; Branched: FA [15iso+15anteiso+16iso+17iso +17 anteiso].

\begin{tabular}{|c|c|c|c|c|c|c|c|}
\hline & \multicolumn{7}{|c|}{ Holothuria scabra } \\
\hline & $T_{0}$ & Unenriched & Maize meal & Fish meal & Unenriched & Maize meal & Fish meal \\
\hline $14: 0$ & $1.8 \pm 0.9$ & $1.7 \pm 0.4$ & $2.4 \pm 0.0$ & $1.8 \pm 0.5$ & $2.6 \pm 0.4$ & $4.0 \pm 2.4$ & $2.6 \pm 0.8$ \\
\hline $15: 0$ & $0.9 \pm 0.7$ & $1.2 \pm 0.4$ & $1.4 \pm 0.6$ & $1.9 \pm 0.8$ & $1.4 \pm 0.2$ & $1.8 \pm 1.0$ & $1.6 \pm 0.6$ \\
\hline $18: 0$ & $17.7 \pm 2.7$ & $10.3 \pm 2.5$ & $7.3 \pm 1.2$ & $13.6 \pm 7.5$ & $11.5 \pm 3.2$ & $8.5 \pm 3.5$ & $10.4 \pm 0.8$ \\
\hline $19: 0$ & $1.4 \pm 1.0$ & $1.5 \pm 0.3$ & $1.5 \pm 0.3$ & $1.1 \pm 0.3$ & $1.3 \pm 0.3$ & $1.5 \pm 1.2$ & $1.8 \pm 0.4$ \\
\hline $20: 0$ & $2.3 \pm 0.4$ & $2.1 \pm 0.3$ & $2.5 \pm 0.5$ & $1.6 \pm 0.3$ & $2.7 \pm 0.6$ & $2.1 \pm 1.3$ & $2.5 \pm 0.5$ \\
\hline $22: 0$ & $4.6 \pm 2.1$ & $3.9 \pm 0.2$ & $5.1 \pm 2.7$ & $2.6 \pm 1.7$ & $5.0 \pm 1.2$ & $3.5 \pm 2.1$ & $4.2 \pm 0.6$ \\
\hline $24: 0$ & $1.9 \pm 0.9$ & $1.4 \pm 0.1$ & $1.5 \pm 0.3$ & $1.0 \pm 0.2$ & $1.2 \pm 0.4$ & $0.7 \pm 0.2$ & $1.2 \pm 0.4$ \\
\hline$\sum$ SFA & $45.2 \pm 8.3$ & $33.6 \pm 2.5$ & $31.0 \pm 4.3$ & $35.2 \pm 6.2$ & $38.6 \pm 8.1$ & $35.7 \pm 5.3$ & $37.8 \pm 4.6$ \\
\hline $18: 1 n-9$ & $5.7 \pm 1.6$ & $4.3 \pm 0.2$ & $7.7 \pm 5.7$ & $4.8 \pm 1.3$ & $4.2 \pm 1.7$ & $5.0 \pm 2.1$ & $3.9 \pm 0.7$ \\
\hline $18: 1 n-7$ & $1.1 \pm 0.7$ & $2.1 \pm 0.0$ & $4.2 \pm 0.7$ & $2.8 \pm 1.0$ & $2.8 \pm 0.5$ & $2.5 \pm 1.4$ & $3.9 \pm 1.1$ \\
\hline $20: 1 n-11$ & $2.1 \pm 0.4$ & $3.5 \pm 1.3$ & $2.4 \pm 0.4$ & $1.9 \pm 1.1$ & $2.6 \pm 0.3$ & $2.8 \pm 2.8$ & $3.2 \pm 2.8$ \\
\hline $22: 1 n-7$ & $2.4 \pm 0.9$ & $2.2 \pm 0.2$ & $3.5 \pm 1.4$ & $1.5 \pm 0.9$ & $2.4 \pm 0.2$ & $2.4 \pm 1.7$ & $2.8 \pm 0.6$ \\
\hline $23: 1 n-9$ & $0.8 \pm 0.5$ & $1.7 \pm 0.0$ & $1.4 \pm 0.5$ & $1.7 \pm 1.0$ & $2.1 \pm 0.1$ & $2.4 \pm 2.5$ & $3.2 \pm 3.0$ \\
\hline $24: 1 n-9$ & $3.2 \pm 1.1$ & $3.1 \pm 0.4$ & $4.7 \pm 2.7$ & $2.9 \pm 1.4$ & $2.9 \pm 0.2$ & $2.7 \pm 2.0$ & $4.0 \pm 0.7$ \\
\hline$\sum$ MUFA & $25.3 \pm 2.8$ & $26.3 \pm 2.2$ & $31.8 \pm 2.0$ & $22.9 \pm 7.3$ & $23.1 \pm 4.2$ & $27.3 \pm 0.6$ & $26.6 \pm 4.1$ \\
\hline $18: 2 n-6$ & $4.8 \pm 3.6$ & $4.7 \pm 1.9$ & $1.5 \pm 1.3$ & $2.8 \pm 2.0$ & $1.8 \pm 1.3$ & $1.2 \pm 0.2$ & $0.8 \pm 0.4$ \\
\hline $18: 4 n-3$ & $2.0 \pm 2.2$ & $1.8 \pm 0.2$ & $1.6 \pm 1.4$ & $1.4 \pm 0.3$ & $1.4 \pm 0.4$ & $1.1 \pm 0.8$ & $0.8 \pm 0.4$ \\
\hline $20: 3 n-3$ & $0.3 \pm 0.4$ & $0.0 \pm 0.0$ & $0.0 \pm 0.0$ & $0.3 \pm 0.2$ & $0.6 \pm 0.4^{b}$ & $8.2 \pm 11.8^{\mathrm{a}}$ & $1.7 \pm 1.4^{\mathrm{ab}}$ \\
\hline $20: 4 n-6$ & $4.3 \pm 0.9$ & $12.3 \pm 2.5$ & $6.5 \pm 1.6$ & $4.4 \pm 2.5$ & $6.4 \pm 1.6$ & $4.3 \pm 3.4$ & $4.4 \pm 2.5$ \\
\hline $20: 5 n-3$ & $2.9 \pm 0.5$ & $7.3 \pm 2.9$ & $7.9 \pm 0.9$ & $4.0 \pm 2.2$ & $4.7 \pm 0.8$ & $3.1 \pm 1.7$ & $4.3 \pm 1.8$ \\
\hline
\end{tabular}

by a specific ${ }^{13} \mathrm{C}$ enriched fraction of sediment. The selective assimilation of a fraction of a composite pool has indeed been reported for various deposit-feeders using SI (Kolasinski et al., 2016). However, the extent of the isotopic lag between sediment and $\mathrm{H}$. scabra (8\%) makes the hypothesis of the consumption of a sole fraction of sediment quite unlikely, and strongly suggests that H. scabra is also feeding on an alternative source, such as biofilm that may fall down on sediment and thus be incorporated into the pool of sedimentary organic matter.

The NL PUFA/SFA ratio provides information relative to the quality of food assimilated by $H$. scabra (Cripps and Atkinson, 2000). This ratio increased in the first 3 months of growth, before decreasing at the end of the experiment, suggesting a shift in food quality. This shift could be related to a growth stop observed for the same experiment by (Hochard et al., 2016). The growth stopped when the total biomass of
H. scabra reached $220 \mathrm{~g} \mathrm{~m}^{-2}$, a value similar to those mentioned in other studies (Battaglene et al., 1999; Pitt et al., 2004). This phenomenon was interpreted as a limit carrying capacity of the system for $H$. scabra that was reached, which is supported by the present results. Interestingly, other studies in more controlled environment (filtered seawater, washed sediment) and also testing the food addition were able to reach much higher biomass for the same species $(600$ $900 \mathrm{~g} \mathrm{~m}^{-2}$ ) (Watanabe et al., 2014; Robinson et al., 2015, 2019), showing thus that this limitation can be controlled from initial conditions. The development of the heterotrophic bacterial production through the manipulation of the $\mathrm{C}: \mathrm{N}$ ration inputs could increase the system carrying capacity (Robinson et al., 2018, 2019). The identification of factors involved in the establishment of the system carrying capacity are still poorly understood and requires further investigation. 

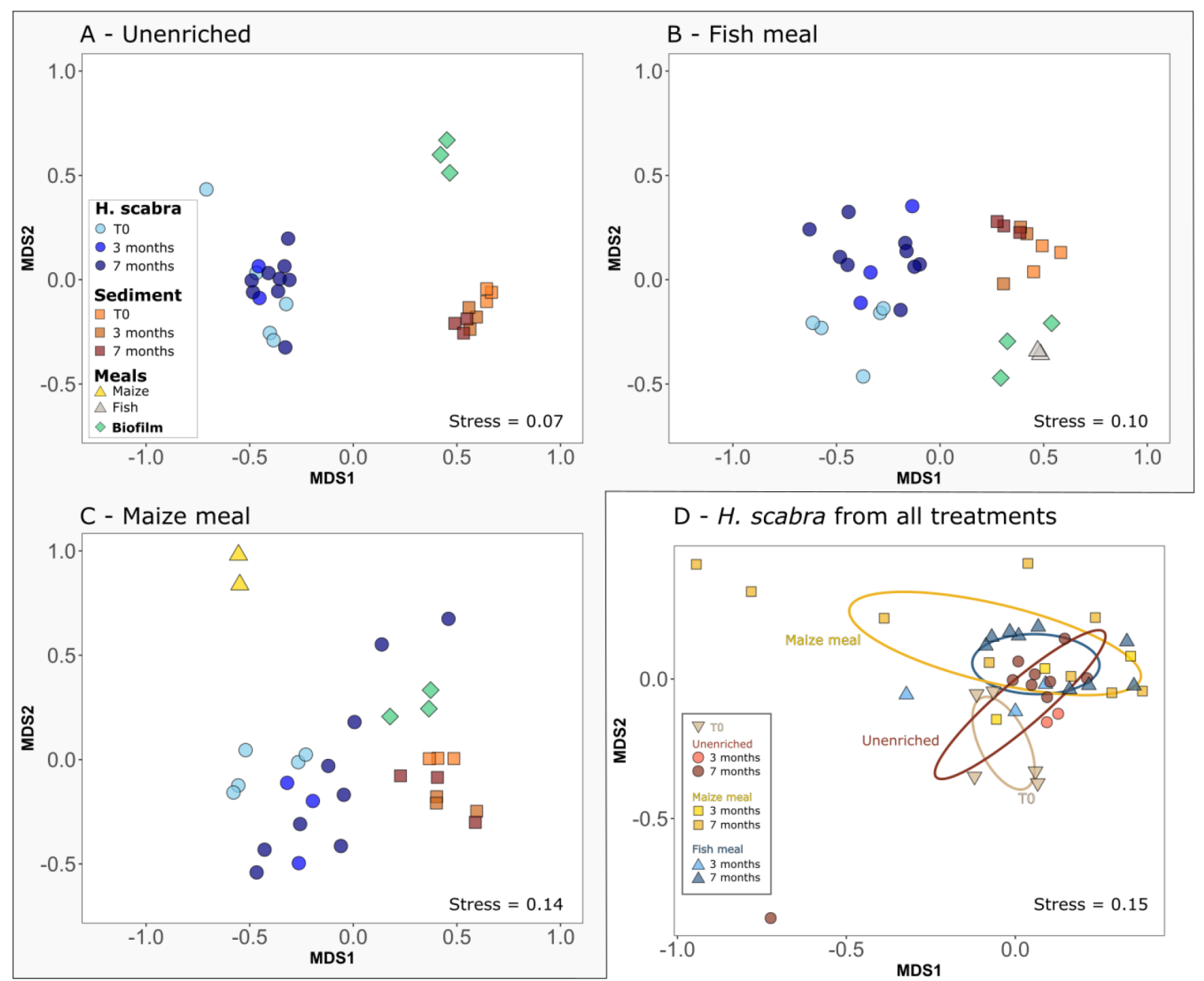

Fig. 2. Multidimensional scaling based on fatty acid composition (mass \%) of Holothuria scabra (neutral lipids) and its potential food sources (total lipids); for the unenriched treatment (A), the fish meal treatment (B), and the maize meal treatment (C). (D) Represent neutral lipid fatty acids of $\mathrm{H}$. scabra from all treatments and associated ellipses for the different feeding conditions.

The NL FA composition of $H$. scabra muscles in all treatments was dominated by the SFA 16:0 and 18:0, which are generally among the most abundant in any marine consumers worldwide (Kelly and Scheibling, 2012), and not informative in a trophic ecology perspective. The content in PUFA was quite low for all treatments $(<20 \%$ for most samples $)$ in comparison to other marine invertebrates, where PUFA often represent up to $50 \%$ of NL (e.g. Soudant et al., 1999). The relatively high abundance of $20: 5 n-3$ and $20: 4 n-6$ has been repeatedly reported in sea-cucumbers from various environments (e.g. Kaneniwa et al., 1986; Drazen et al., 2008; Yu et al., 2015). In particular, the content in 20:4n-6 was surprisingly high in $H$. scabra (up to $12 \%$ ) considering that it was almost absent from all sources, at the exception of the biofilm, where it reached $4 \%$ of total FA. This highlights the capacities of $H$. scabra to synthesize de novo or to selectively incorporate specific FA. Echinoderms have been shown capable to synthesize several PUFA when they are lacking in their diet, while most other marine animals have very limited PUFA biosynthesis capacities (Kelly and Scheibling, 2012). Finally, branched FA and 18:1n-7 represented non-negligible amounts in muscles of $H$. scabra (their total content reached up to $12 \%$ ), which represents an evidence of shrimp farm sediment assimilation by holothurids.

Both tracers support a contribution of biofilm growing on tanks walls to the diet of $H$. scabra. Such conclusion about biofilm contribution should however be only valid for our experimental conclusions. Indeed, because of the relatively small size of the tanks where the experiment took place, the biofilm covering tanks walls did represent an abundant available food source because of high wall surface/sediment area ratio, while its contribution to the diet of holothurids should be reduced in larger ponds, where this ratio is lower. In addition to be a potential food source for animals, some studies shown that the utilization of additional substrates where biofilm can grow contribute to improving water quality, and could also increase the productivity of systems (Milstein, 2005; Khatoon et al., 2007). The accurate evaluation of each food source contribution to the diet of sea cucumbers with SI mixing models requires a reliable evaluation of trophic fractionation, as well as a proper characterization of endmembers. The trophic fractionation of organisms during intense growth phases is highly variable (Gorokhova and Hansson, 1999), hence using such a coefficient from the 
literature would make no sense for this purpose in this case study. Moreover, our results suggest that only a ${ }^{13} \mathrm{C}$-enriched fraction of sedimentary organic matter is assimilated, whose SI characterization is not possible.

\subsection{Effect of additional food sources on the trophic ecology of $H$. scabra}

Sea cucumbers reared on sediment with additional maize meal supplementation displayed a significant increase of their $\delta{ }^{15} \mathrm{~N}$. At the end of the experiment, their SI composition was in accordance with what could be expected if they were only feeding on maize meal, considering commonly accepted mean isotope fractionation values (e.g. $0.8 \%$ o for $\Delta \delta 13 \mathrm{C}$ (Vander Zanden and Rasmussen, 2001), 2.5\%o for $\Delta \delta 15 \mathrm{~N}$ (Vanderklift and Ponsard, 2003)). However, no significant difference could be observed between individuals for which maize meal was available and those for which this source was absent, suggesting that the similarity between the SI composition of maize meal and $H$. scabra might just as well be a coincidence, and that maize would not be assimilated by H. scabra. This hypothesis is strengthened by the analysis of FA composition. The most important maize meal unsaturated FA (18:1n-9 and 18:2n-6) were indeed not present in higher abundances in individuals fed maize meal compared to fish meal and unenriched treatments.

In contrast to other treatments, $H$. scabra subjected to fish meal supplementation displayed a significant marked increase in the $\delta^{15} \mathrm{~N}$, likely related to the high $\delta^{15} \mathrm{~N}$ of fish meals. This suggests that nitrogen compounds from fish meal are assimilated by H. scabra. However, this hypothesis does not fit with $\delta^{13} \mathrm{C}$ values, for which there was a clear difference (5.3\%o) between fish meal and H. scabra. In fact the $\delta^{13} \mathrm{C}$ of H. scabra from fish meal-supplemented conditions was only significantly different from unenriched but not from maize meal treatment. Moreover, the most abundant FA found in fish meals, especially 20:5n-3 (EPA) and 22:6n-3 (DHA), were not found at higher levels in individuals supplemented with fish meal. Because FA do not contain nitrogen, they only reflect the assimilation of carbon, and do not support a dependence of H. scabra towards fish meal. Both SI and FA therefore support the lack of carbon assimilation from fish meal within these mesocosms, although nitrogen seemed to contribute to the growth of holothurids. The differential integration of carbon and nitrogen from this source could arise from a differential digestibility of carbon and nitrogen compounds. Orozco et al. (2014) reported a marked difference in the assimilation of proteins ( $\mathrm{N}$ dominated compounds) and carbohydrates (C dominated compounds) from shrimp powder by H. scabra. The apparent digestibility coefficient was three time higher for proteins $(90 \%)$ than for carbohydrates $(30 \%)$. If these inputs of organic matter did enrich the environment (sediment and biofilm), they did not seem to increase the productivity of animals, suggesting limiting mechanisms, which could affect the palatability of food, and/or the alteration of the nutrients transfer via microbial loop. Alternatively, these results could result from an indirect consumption of fish meal in the system as also suggested recently by Robinson et al. (2019). Holothurids are indeed in competition with a diversity of macro and meiofaunal organisms for the assimilation of food, and can ingest both fresh and recycled organic matter. This illustrates the complexity of the benthic system and show the difficulties emerging from the culture of detritus-feeders.

\section{Conclusion}

This study supports the assimilation of shrimp farm sediment by holothurids, which could therefore represent a solution to pond sediment excessive organic matter enrichment associated with shrimp farming. We also showed that although carbon and nitrogen compounds from maize meal was not assimilated by holothurids, fish meal could represent an indirect source of nitrogen compounds into their tissues. However, discrepancies between the assimilation of nitrogen and carbon from this food source, as well as the growth stop observed during the experiment highlight the need to provide holothurids with a stoichiometrically balanced diet for a more efficient assimilation of sedimentary organic matter. Although our study presents some experimental limitations (in particular linked to density-dependent regulation of growth and feeding) which are inherent, to this kind of approach, we are confident that the patterns observed here concerning nutrient assimilation are quite robust to these biases. Finally, even if the assimilation of sediment was clear, this study could not reveal any significant effect of holothurids on the FA and SI composition of pond sediment. Evaluating the effects of such supplementation on $H$. scabra growth performances and tissue turnover is the next step toward assessing the relevance of this treatment, from both ecological and economic perspectives.

\section{Conflict of interest}

The authors declare no conflict of interest whatsoever concerning the results presented in this manuscript.

\section{Animal experiments}

Animals used in this study were used in experiments in euthanized complying with national rules regarding animal experiments.

\section{Informed consent}

All authors listed here read and agreed with the submitted version of this manuscript.

Acknowledgements. This research was financed by the ZONECO program of New Caledonia and the Ministry of Overseas Territories (Ministère de l'Outre Mer). We thankFlorence Royer and Morgane Hubert for their helpful participation in the sample acquisition and preparation. The LIPIDOCEAN analytical facility (University of Western Brittany, France) is acknowledged for hosting all fatty acids analyses.

\section{References}

Arts MT, Ackman RG, Holub BJ. 2001. "Essential fatty acids" in aquatic ecosystems: a crucial link between diet and human health and evolution. Can J Fish Aquat Sci 58: 122-137. 
Battaglene SC, Seymour JE, Ramofafia C. 1999. Survival and growth of cultured juvenile sea cucumbers, Holothuria scabra. Aquaculture 178: 293-322.

Bell JD, Agudo NN, Purcell SW, Blazer P, Simutoga M, Pham D, Della Patrona L. 2007. Grow-out of sandfish Holothuria scabra in ponds shows that co-culture with shrimp Litopenaeus stylirostris is not viable. Aquaculture 273: 509-519.

Burford MA, Peterson EL, Baiano JCF, Preston NP. 1998. Bacteria in shrimp pond sediments: their role in mineralizing nutrients and some suggested sampling strategies. Aquac Res 29: 843-849.

Chen Y, Hu C, Ren C. 2015a. Application of wet waste from shrimp (Litopenaeus vannamei) with or without sea mud to feeding sea cucumber (Stichopus monotuberculatus). J Ocean Univ China 14: 114-120.

Chen Y, Luo P, Hu C, Ren C. 2015b. Effect of shrimp (Litopenaeus vannamei) farming waste on the growth, digestion, ammonium-nitrogen excretion of sea cucumber (Stichopus monotuberculatus). J Ocean Univ China 14: 484-490.

Core Team R. 2017. R: A language and environment for statistical computing. Vienna, Austria: R Foundation for Statistical Computing. Available at https://www.R-project.org/

Cripps GC, Atkinson A. 2000. Fatty acid composition as an indicator of carnivory in Antarctic krill, Euphausia superba. Can J Fish Aquat Sci 57: 31-37.

Dalsgaard J, St. John M, Kattner G, Müller-Navarra D, Hagen W. 2003. Fatty acid trophic markers in the pelagic marine environment. Adv Mar Biol 46: 225-340.

Della Patrona L, Brun P. 2008. Elevage de la Crevette Bleue en Nouvelle-Calédonie Litopenaeus stylirostris: bases biologiques et zootechnie. Dép. LEAD Lab. Ecosystème Aquac. Durable En Nouv. -Caléd.

DeNiro MJ, Epstein S. 1978. Influence of diet on the distribution of carbon isotopes in animals. Geochim Cosmochim Acta 42: 495-506.

Drazen JC, Phleger CF, Guest MA, Nichols PD. 2008. Lipid, sterols and fatty acid composition of abyssal holothurians and ophiuroids from the North-East Pacific Ocean: food web implications. Comp Biochem Physiol B Biochem Mol Biol 151: 79-87.

Feng J-X., Gao Q-F., Dong S-L., Sun Z-L., Zhang K. 2014. Trophic relationships in a polyculture pond based on carbon and nitrogen stable isotope analyses: a case study in Jinghai Bay, China. Aquaculture 428: 258-264.

Gao Q-F, Wang Y, Dong S, Sun Z, Wang F. 2011. Absorption of different food sources by sea cucumber Apostichopus japonicus (Selenka) (Echinodermata: Holothuroidea): evidence from carbon stable isotope. Aquaculture 319: 272-276.

Gorokhova E, Hansson S. 1999. An experimental study on variations in stable carbon and nitrogen isotope fractionation during growth of Mysis mixta and Neomysis integer. Can J Fish Aquat Sci 56: 2203-2210.

Hochard S, Ducrocq M, Lemonnier H, Royer F, Hubert M, Michaut H, Verge R, Letourneur Y, Lorrain A, Mathieu-Resuge M. 2016. Holothurie: Lien entre performances de production et de bioremédiation dans le contexte de la crevetticulture en Nouvelle-Calédonie. Projet Hobical.

Kaneniwa M, Itabashi Y, Endo S, Takagi T. 1986. Fatty acids in Holothuroidea: occurrence of cis-14-tricosenoic acid. Comp Biochem Physiol Part B Comp Biochem 84: 451-455.

Kelly JR, Scheibling RE. 2012. Fatty acids as dietary tracers in benthic food webs. Mar Ecol Prog Ser 446: 1-22.
Kharlamenko VI, Kiyashko SI, Imbs AB, Vyshkvartzev DI. 2001. Identification of food sources of invertebrates from the seagrass Zostera marina community using carbon and sulfur stable isotope ratio and fatty acid analyses. Mar Ecol Prog Ser 220: 103-117.

Khatoon H, Yusoff F, Banerjee S, Shariff M, Bujang JS. 2007. Formation of periphyton biofilm and subsequent biofouling on different substrates in nutrient enriched brackishwater shrimp ponds. Aquaculture 273: 470-477.

Kolasinski J, Nahon S, Rogers K, Chauvin A, Bigot L, Frouin P. 2016. Stable isotopes reveal spatial variability in the trophic structure of a macro-benthic invertebrate community in a tropical coral reef. Rapid Commun Mass Spectr 30: 433-446.

Le Grand F, Soudant P, Marty Y, Le Goïc, N, Kraffe E. 2013. Altered membrane lipid composition and functional parameters of circulating cells in cockles (Cerastodermaedule) affected by disseminated neoplasia. Chemistry and physics of lipids 167: 9-20.

Lemonnier H. 2007. Effet des conditions environnementales sur le développement des pathologies à Vibrio dans les élevages de crevettes en Nouvelle-Calédonie. La Rochelle.

Lemonnier H, Courties C, Mugnier C, Torréton J-P., Herbland A. 2010. Nutrient and microbial dynamics in eutrophying shrimp ponds affected or unaffected by vibriosis. Mar Pollut Bull 60: 402-411.

Lemonnier H, Herbland A, Salery L, Soulard B. 2006. "Summer syndrome" in Litopenaeus stylirostris grow out ponds in New Caledonia: zootechnical and environmental factors. Aquaculture 261: 1039-1047.

Li J, Dong S, Gao Q, Wang F, Tian X, Zhang S. 2014a. Total organic carbon budget of integrated aquaculture system of sea cucumber Apostichopus japonicus, jellyfish Rhopilema esculenta and shrimp Fenneropenaeus chinensis. Aquac Res 45: 1825-1831.

Li J, Dong S, Gao Q, Zhu C. 2014b. Nitrogen and phosphorus budget of a polyculture system of sea cucumber (Apostichopus japonicus), jellyfish (Rhopilema esculenta) and shrimp (Fenneropenaeus chinensis). J Ocean Univ China 13: 503-508.

Lutz CG. 2003. Polyculture: principles, practices, problems and promise. Aquac Mag 29: 34-39.

MacTavish T, Stenton-Dozey J, Vopel K, Savage C. 2012. Depositfeeding sea cucumbers enhance mineralization and nutrient cycling in organically-enriched coastal sediments. PloS ONE 7: e50031.

Mangion P, Taddei D, Conand C, Frouin P. 2004. Feeding rate and impact of sediment reworking by two deposit feeders Holothuria leucospilota and Holothuria atra on a fringing reef (Reunion Island, Indian Ocean). Echinoderms Munchen 52: 311-317.

Marty Y, Delaunay F, Moal J, Samain, JF. 1992. Changes in the fatty acid composition of Pectenmaximus (L.) during larval development. Journal of Experimental Marine Biology and Ecology 163: 221-234.

Meziane T, Tsuchiya M. 2000. Fatty acids as tracers of organic matter in the sediment and food web of a mangrove/intertidal flat ecosystem, Okinawa, Japan. Mar Ecol Prog Ser 200: 49-57.

Milstein A. 2005. 10 Effect of Periphyton on Water Quality. Periphyton Ecol Exploit Manag 179.

Moriarty DJW. 1982. Feeding of Holothuria atra and Stichopus chloronotus on bacteria, organic carbon and organic nitrogen in sediments of the Great Barrier Reef. Mar Freshw Res 33: $255-263$. 
Neofitou N, Lolas A, Ballios I, Skordas K, Tziantziou L, Vafidis D. 2019. Contribution of sea cucumber Holothuria tubulosa on organic load reduction from fish farming operation. Aquaculture 501: 97-103.

Orozco ZGA, Sumbing JG, Lebata-Ramos MJH, Watanabe S. 2014, Apparent digestibility coefficient of nutrients from shrimp, mussel, diatom and seaweed by juvenile Holothuria scabra Jaeger. Aquac Res 45: 1153-1163.

Pinnegar JK, Polunin NVC. 1999. Differential fractionation of $\delta{ }^{13} \mathrm{C}$ and $\delta^{15} \mathrm{~N}$ among fish tissues: implications for the study of trophic interactions. Funct Ecol 13: 225-231.

Pitt R, Duy NDQ, Duy TV, Long HTC. 2004. Sandfish (Holothuria scabra) with shrimp (Penaeus monodon) co-culture tank trials. SPC Beche-Mer Inf Bull 20: 12-22.

Purcell SW. 2004. Rapid growth and bioturbation activity of the sea cucumber Holothuria scabra in earthen ponds. Proc Australas Aquac 1: 244.

Purcell SW, Patrois J, Fraisse N. 2006. Experimental evaluation of co-culture of juvenile sea cucumbers, Holothuria scabra (Jaeger), with juvenile blue shrimp, Litopenaeus stylirostris (Stimpson). Aquac Res 37: 515-522.

Roberts D, Gebruk A, Levin V, Manship BAD. 2003. Feeding and digestive strategies in deposit-feeding holothurians. Oceanogr Mar Biol Annu Rev 38: 257-310.

Robinson G, Caldwell GS, Jones CL, Slater MJ, Stead SM. 2015. Redox stratification drives enhanced growth in a deposit-feeding invertebrate: implications for aquaculture bioremediation. Aquac Environ Interact 8: 1-13.

Robinson G, Caldwell GS, Jones CL, Stead SM. 2019. The effect of resource quality on the growth of Holothuria scabra during aquaculture waste bioremediation. Aquaculture 499: 101-108.

Robinson G, Caldwell GS, Wade MJ, Free A, Jones CL, Stead SM. 2016. Profiling bacterial communities associated with sediment-based aquaculture bioremediation systems under contrasting redox regimes. Sci Rep 6: 38850 .

Robinson G, MacTavish T, Savage C, Caldwell GS, Jones CL, Probyn T, Eyre BD, Stead SM. 2018. Carbon amendment stimulates benthic nitrogen cycling during the bioremediation of particulate aquaculture waste. Biogeosciences 15: 1863-1878.

Sadeghi-Nassaj SM, Batanero GL, Mazuecos IP, Alonso C, Reche I. 2018, Sea cucumbers reduce nitrogen, bacteria and transparent exopolymer particles in Anemonia sulcata aquaculture tanks. Aquac Res 49: 3669-3681.

Slater MJ, Carton AG. 2007. Survivorship and growth of the sea cucumber Australostichopus (Stichopus) mollis (Hutton 1872) in polyculture trials with green-lipped mussel farms. Aquaculture 272: 389-398.

Slater MJ, Carton AG. 2010, Sea cucumber habitat differentiation and site retention as determined by intraspecific stable isotope variation. Aquac Res 41: e695-e702.
Slater MJ, Lassudrie M, Jeffs AG. 2011. Method for determining apparent digestibility of carbohydrate and protein sources for artificial diets for juvenile sea cucumber, Australostichopus mollis. $J$ World Aquac Soc 42: 714-725.

Soto D. 2009. Integrated mariculture: a global review. Food and Agriculture Organization of the United Nations (FAO).

Soudant P, Van Ryckeghem K, Marty Y, Moal J, Samain JF, Sorgeloos P. 1999. Comparison of the lipid class and fatty acid composition between a reproductive cycle in nature and a standard hatchery conditioning of the Pacific Oyster Crassostrea gigas. Comp Biochem Physiol B 123: 209-222.

Vander Zanden MJ, Rasmussen JB. 2001. Variation in $\delta^{15} \mathrm{~N}$ and $\delta^{13} \mathrm{C}$ trophic fractionation: implications for aquatic food web studies. Limnol Oceanogr 46: 2061-2066.

Vanderklift MA, Ponsard S. 2003. Sources of variation in consumerdiet $\delta 15 \mathrm{~N}$ enrichment: a meta-analysis. Oecologia 136: $169-182$.

Volkman JK, Jeffrey SW, Nichols PD, Rogers GI, Garland CD. 1989. Fatty acid and lipid composition of 10 species of microalgae used in mariculture. J Exp Mar Biol Ecol 128: 219-240.

Watanabe S, Kodama M, Zarate JM, Lebata-Ramos MJ, Nievales MF. 2012. Ability of sandfish (Holothuria scabra) to utilise organic matter in black tiger shrimp ponds. Proc Asia Pac Trop Sea Cucumber Aquac Aust Cent Int Agric Res Canberra 113-120.

Watanabe S, Sumbing JG, Lebata-Ramos MJH. 2014. Growth pattern of the tropical sea cucumber, Holothuria scabra, under captivity. Jpn Agric Res $Q$ 48: 457-464.

$\mathrm{Xu} \mathrm{G}$, Zhu S. 2002. Technique for polyculture of shrimp and sea cucumber. China Fish 6: 42-43.

Yokoyama H. 2013. Growth and food source of the sea cucumber Apostichopus japonicus cultured below fish cages-potential for integrated multi-trophic aquaculture. Aquaculture 372: $28-38$.

Yu H-B, Gao Q-F, Dong S-L, Wen B. 2015. Changes in fatty acid profiles of sea cucumber Apostichopus japonicus (Selenka) induced by terrestrial plants in diets. Aquaculture 442: 119-124.

Zamora LN, Jeffs AG. 2015. Macronutrient selection, absorption and energy budget of juveniles of the A ustralasian sea cucumber, A ustralostichopus mollis, feeding on mussel biodeposits at different temperatures. Aquac Nutr 21: 162-172.

Zamora LN, Yuan X, Carton AG, Slater MJ. 2016. Role of depositfeeding sea cucumbers in integrated multitrophic aquaculture: progress, problems, potential and future challenges. Rev Aquac 10: 900.

Zhang L, Song X, Hamel J-F., Mercier A. 2015. Aquaculture, stock enhancement, and restocking. In: Developments in Aquaculture and Fisheries Science. Elsevier, pp. 289-322.

Cite this article as: Mathieu-Resuge M, Le Grand F, Schaal G, Kraffe E, Lorrain A, Letourneur Y, Lemonnier H, Benoît J, Hochard S. 2020. Assimilation of shrimp farm sediment by Holothuria scabra: a coupled fatty acids and stable isotopes approach. Aquat. Living Resour. 33: 3 